\title{
Biogas Production and Greenhouse Gas (GHG) Emissions Reduction due to Use of Biogas Digesters in Small Farms in Quang Tri Province, Vietnam
}

\author{
H.T. Hoang* and T. Kato**† \\ *Graduate School of Environmental Engineering, The University of Kitakyushu, Kitakyushu, Fukuoka 808-0135, Japan \\ **Faculty of Environmental Engineering, The University of Kitakyushu, Kitakyushu, Fukuoka 808-0135, Japan \\ †Corresponding author: T. Kato; tkato@kitakyu-u.ac.jp
}

Nat. Env. \& Poll. Tech.

Website: www.neptjournal.com

Received: 14-06-2021

Revised: 28-06-2021

Accepted: 03-09-2021

\section{Key Words:}

Biogas digester

Livestock waste treatment

Greenhouse gas reduction

Environmental impacts

Biogas production

\section{ABSTRACT}

This research aims to assess the greenhouse gas (GHG) emissions reductions due to the use of biogas technology in Quang Tri Province. With a total of over 354,000 cattle in Quang Tri Province, Vietnam, waste from livestock becomes large. The GHG emitted from the livestock industry is not small, affecting the environment. Currently, there is little concern or documentation about the reduction of GHG emissions in small farms using biogas digesters in central Vietnam. This province has applied technological solutions, typically biogas digesters, but the amount of biogas production is not calculated accurately. Our survey was conducted in Vinh Linh District and Cam Lo District in March 2019 and involved 50 farms equipped with biogas digesters and 20 farms without it. The respondents were selected based on the information provided by local authorities, satisfying two conditions: livestock households and biogas users. The former group was asked 25 questions and the latter was asked 10 questions needed to calculate GHG emissions such as the number of animals and petroleum gas/ firewood consumption. This study uses formulas described in the 2006 guideline issued by IPCC to estimate reduced GHG emissions. The results showed that the average biogas production is 5.52 $\mathrm{m}^{3}$.household ${ }^{-1}$.day ${ }^{-1}$. Only $2 \%$ of the farms made the best use of the biogas digester. The surveyed households have not really used the most optimal amount of biogas production. In this scenario, this study recommends some solutions for solving the problem. In addition, the average annual emissions before having a biogas digester are estimated to be 20.53 tons $\mathrm{CO}_{2} \mathrm{e} /$ household/year. After using the biogas, the GHG emissions are reduced to $4.52 \mathrm{tCO}_{2} \mathrm{e}$.household ${ }^{-1}$.day ${ }^{-1}$. Thus, the replacement of daily cooking energies with biogas helps reduce $16.01 \mathrm{tCO}_{2} \mathrm{e}$ of greenhouse gas for each farm per year.

\section{INTRODUCTION}

With the current growth of the livestock industry in Vietnam, based on calculations based on animal physiological science and statistics, it can be seen that the solid waste emissions of livestock raising rate increases according to the scale growth, with the average emission estimated at $1.5 \mathrm{~kg}$ of pig manure. head $^{-1}$.day ${ }^{-1}, 15 \mathrm{~kg}$ of buffalo, cow manure.head ${ }^{-1}$. lay $^{-1}$, and $0.2 \mathrm{~kg}$ of poultry manure.head ${ }^{-1}$.day $^{-1}$ (Quang Tri Department of Agriculture and Rural Development 2016). The average annual emission from the entire country's livestock population is much more than 85 million tonnes, with tens of billions of cubic meters of liquid waste and hundreds of millions of tonnes of gas waste. However, the management and treatment of animal waste have not been given due attention. The main reason is due to the low awareness and responsibility of farm owners. Most farmers do not have proper waste treatment measures, thus environmental pollution in livestock has not been completely overcome and tends to increase.

In this circumstance, low-cost biogas digesters are a good selection for reducing environmental impacts and improving the standard of living of rural families. Low-cost digesters are considered to be a clean and environmentally friendly technology that can help small-scale farmers to treat livestock waste in a sustainable way while producing biofertilizer (digestate) and meeting their energy needs (i.e., by providing biogas) (Kinyua et al. 2016). Biogas refers to the collection of gases from the decomposition and fermentation of animal, human, and plant waste resulting from the lack of oxygen and the activities of anaerobic bacteria in anaerobic digestion. This is an effective way of minimizing the negative impacts of animal waste on the environment and human health. Since the installation of the biogas digester, pollution has been reduced, households can now use the gas produced, and also families have a clean environment, which helps people get out of the air pollution caused by animal waste. Realizing the potential benefits from biogas, the Vietnamese government, local authorities, as well as farmers, have decided to invest in this renewable technology. The number of household biogas digesters has considerably increased in Vietnam during the past two decades (Nguyen 2011, Nguyen et al. 2012). According to Teune (2007), there 
were over 200,000 small-scale biogas digesters in use in Vietnam in 2007. This figure continued to rise, with around 500,000 biogas digesters installed in livestock farms across the country (Mayhew 2015, Ho et al. 2015).

Nowadays, global warming and climate change are issues of great concern. Even though environmental advantages are more significant when biogas production fully satisfies a family's cooking needs or in large-scale projects, household biogas digesters offer a viable approach for reducing GHG emissions. Biogas digesters are currently used for cooking and lighting in many developing countries and can provide an alternative energy source from traditional fuels such as firewood and liquefied petroleum gas (Hessen 2014, Mengistu et al. 2015, Roopnarain \& Adeleke 2017). Zhang et al. (2013) showed that the long-term, stable running of a household biogas technology is potential in quantifying carbon emission reduction in rural China. The use of biogas technology has led to a dramatic reduction in the consumption of fossil fuels, and a reduction in fueling problems, especially in rural areas of the developing country.

This study aims to make an assessment of biogas production in Quang Tri Province located in the central of Vietnam. In addition, a study was conducted to determine the potential for household-scale biogas digesters to reduce GHG emissions from livestock production, thereby analyzing the development potential of biogas digesters in Vietnam.

\section{MATERIALS AND METHODS}

\section{Research Materials}

Our data compilation comprised both primary and secondary data. The primary data of the study was gathered via the questionnaire-based survey. An in-person interview was conducted in Vinh Linh District and Cam Lo District in Quang Tri Province as shown in Fig. 1 from February $26^{\text {th }}$ to March $7^{\text {th }}, 2019$ by the first author of this article. The survey involved 70 households including 50 farms equipped with a biogas digester and 20 farms without it. The 25 -item questionnaire was used to conduct in-person interviews of the 50 households with a biogas digester. The remaining 20 households without a biogas digester were interviewed with a questionnaire consisting of 10 questions. The questionnaire was created to collect detailed information about household biogas use in terms of economic, environmental, and social factors such as the number of pigs that households are raising, and the consumption of fuel (i.e., gas, firewood, coal, etc.) before and after the installation of the digester. This interview method was combined with site visits to biogas digesters to collect reliable information. The secondary techno-economic data was gathered from the Department of Agriculture and Rural Development in Quang Tri Province.

\section{Research Methods}

The statistical methods used in this study to obtain the key results are explained below.

\section{Method of Calculating the Amount of Biogas Produced}

This research uses the feedstock use method from International Renewable Energy Agency (IRENA) to calculate the amount of biogas production and consumption. According to IRENA, there are five methodologies for estimating biogas production. Estimates can be based on digester capacity, appliance use, or feedstock use, or by comparing the fuel use in households with and without a biogas digester. Biogas production may also be measured directly.

Here, the feedstock use method is used to calculate the amount of biogas produced. This method calculates the biogas production based on feedstock use rather than assumptions about the capacity utilization of biogas digesters. To apply this method, it is necessary to collect data on digester sizes, digester technology, and feedstock use. Biogas production is calculated for a wide range of temperatures and retention times, as follows (IRENA 2016 p.16):

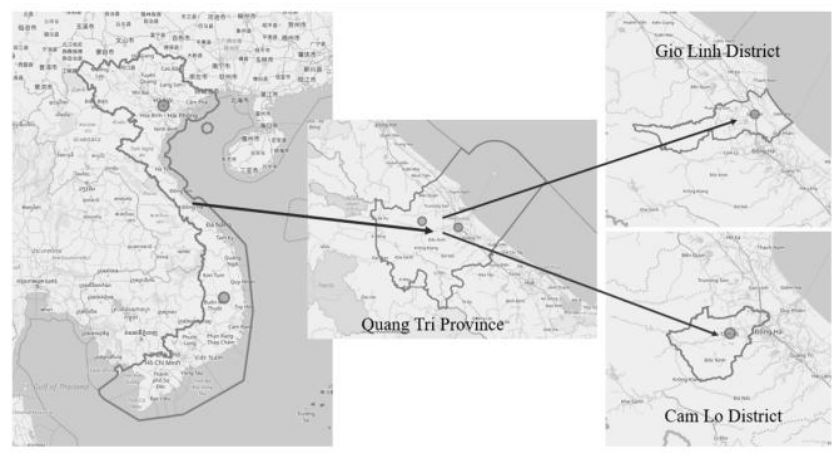

Fig. 1: The map of the survey area. (OpenStreetMap is used for these maps) 


$$
G=\frac{Y \times V_{d} \times S}{1000}
$$

Where:

$G=$ the biogas production, $\mathrm{m}^{3} \cdot$ day $^{-1}$

$Y=$ a yield factor based on temperature and the feedstock retention time

$V_{d}=$ the biogas digester volume, $\mathrm{m}^{3}$

$S=$ the initial concentration of volatile solids in the slurry, kg.m ${ }^{-3}$

The digester volume $\left(V_{d}\right)$ was obtained by asking the farmers in our survey. The initial concentration of volatile solids $(S)$ was calculated as follows. First, the total feedstock volume was estimated. In the two districts in Quang Tri Province selected for this research, the main input source of biogas digesters is pig manure. The surveyed households did not have a large population of cows, buffaloes, or poultry, and the amount of manure from these animals was small. Thus, we considered only pig manure. According to Table 5 in IRENA (2016), the total animal waste feedstock per day for each pig is $5 \mathrm{~kg}$, of which the volatile solids account for $1 \mathrm{~kg}$. These numbers were multiplied by the number of pigs reported in our survey to estimate the total daily weight of animal waste and volatile solids. Assuming that $1 \mathrm{~kg}$ of animal waste is approximately equal to a volume of $1 \mathrm{~L}$, we obtained the volume of the pig waste. This waste volume was multiplied by 3 to obtain the daily feedstock volume, because we learned that the local government recommended that farmers add a volume of water equal to as much as twice the volume of waste to operate the digesters. The initial concentration of volatile solids $(S)$ was calculated by dividing the daily weight of volatile solids by this daily feedstock volume. To determine the yield factor $(Y)$ from Table 7 in IRENA (2016), the temperature in the digester and the feedstock retention time $(R)$ are necessary. The average temperature in Quang Tri Province is $25^{\circ} \mathrm{C}$ (Doan et al. 2014), and the digester temperature is $2^{\circ} \mathrm{C}$ higher when the digester is located underground; thus, the temperature range is $25-27^{\circ} \mathrm{C}$. The feedstock retention time was estimated by dividing the digester volume by the daily feedstock volume.

\section{Method of Calculating Greenhouse Gas Emissions Reduction}

The effect of reducing greenhouse gas emissions when using biogas is realized by calculating the difference between the amount of greenhouse gas emissions before and after the use of biogas digesters by households. Following the guidance of the Intergovernmental Panel on Climate Change (IPCC 2006), a number of key greenhouse gases have been selected to calculate emissions from manure pits, fuel combustion, and biogas leakage. In addition, the parameters used for calculating greenhouse gas emissions are also referenced by IPCC (2006). Fig. 2 shows the system boundary of greenhouse gas emissions calculation before and after using the biogas digesters that were used for calculating in this study.

The process of calculating the amount of greenhouse gas emissions before using the biogas digesters is made according to the following formulas:

\section{Calculating the Average GHG Emissions Before the Households Use the Biogas Digesters (IPCC 2006)}

Step 1: Determining $\mathrm{CH}_{4}$ emission factor from pig manure

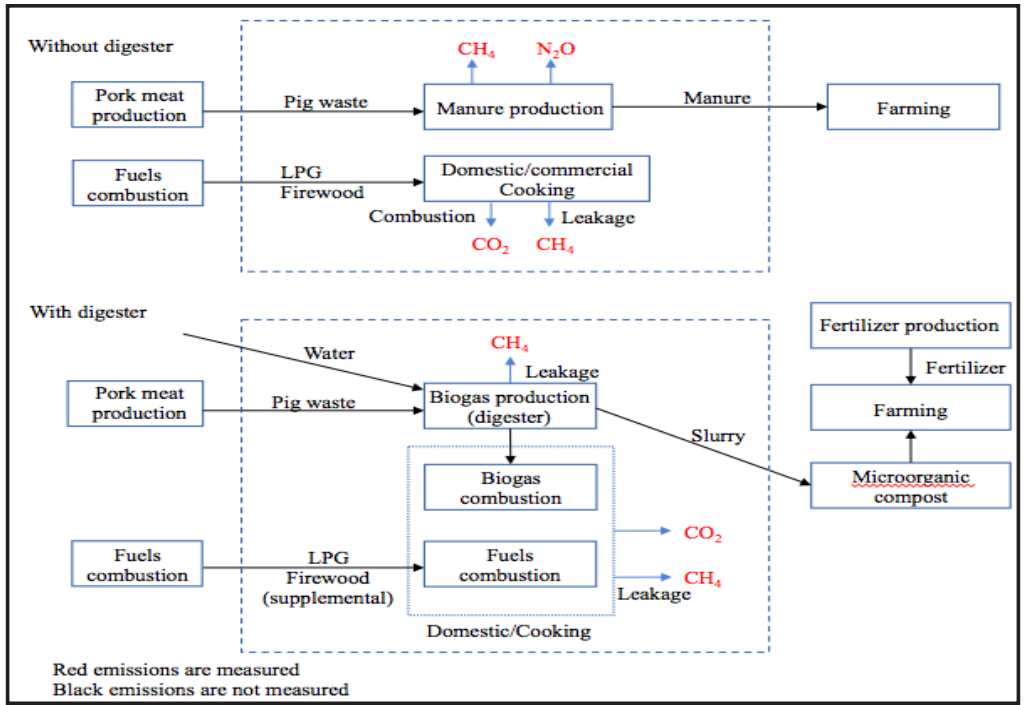

Fig. 2: System boundary of greenhouse gas emissions calculation before and after using the biogas digesters. 
corresponding to climatic conditions of Quang Tri Province

$$
\begin{aligned}
E F_{(T)}= & \left(V S_{(T)} \times 365\right) \times\left[B_{o(T)} \times 0.67 \mathrm{~kg} / \mathrm{m}^{3}\right. \\
& \left.\times \sum_{S, k} \frac{M C F_{S, k}}{100} \times M S_{(T, S, k)}\right]
\end{aligned}
$$

Where:

$E F_{(T)}=$ annual $\mathrm{CH}_{4}$ emission factor for livestock category $T$, kg. $\mathrm{CH}_{4} \cdot$ animal $^{-1}$. year $^{-1}$

$V S_{(T)}=$ daily volatile solid excreted for livestock category $T$, kg.dry matter ${ }^{-1}$.animal. ${ }^{-1}$.day ${ }^{-1}$

$365=$ basis for calculating annual VS production, days/year $B_{o(T)}=$ maximum methane producing capacity for manure produced by livestock category $T, \mathrm{~m}^{3} \cdot \mathrm{CH}_{4}{ }^{-1} \mathrm{~kg}^{-1}$ of VS excreted

$0.67=$ conversion factor of $\mathrm{m}^{3} . \mathrm{CH}_{4}{ }^{-1}$ to $\mathrm{kg} \cdot \mathrm{CH}_{4}{ }^{-1}$

$M C F_{(S, k)}=$ methane conversion factors for each manure management system $S$ by climate region $k, \%$

$M S_{(T, S, k)}=$ fraction of livestock category $T$ "'s manure handled using manure management system $S$ in climate region $k$, dimensionless

According to IPCC (2006), the calculation coefficients are as follows: the annual average temperature of Quang Tri Province is $25^{\circ} \mathrm{C}$, the daily volatile solid (VS) excreted from pigs is $0.30 \mathrm{~kg}$ per head, maximum methane producing capacity by pig $B_{o}$ is $0.29 \mathrm{~m}^{3} \cdot \mathrm{kg}^{-1}$ of $V S$ excreted, methane correction factor $M C F$ for the manure treatment system is $65 \%$, the handled fraction of manure management $M S$ equals to $100 \%$.

Step 2: Calculating $\mathrm{CH}_{4}$ emission factor from manure management:

$$
\mathrm{CH}_{4 \text { (manure })}=G W P_{\mathrm{CH}_{4}} \times N_{(T)} \times E F_{(T)} \times 10^{-3}
$$

Where:

$\mathrm{CH}_{4 \text { (manure) }}=\mathrm{CH}_{4}$ emissions from manure management, for a defined population, $\mathrm{tCO}_{2}$ e.year ${ }^{-1}$
$G W P_{C H 4}=28$ : the possibility of causing $\mathrm{CH}_{4}$ greenhouse effect compared to $\mathrm{CO}_{2}$

$E F_{(T)}=$ emission factor for the defined livestock population, $\mathrm{kg} \mathrm{CH}_{4} \cdot$ head $^{-1}$. year $^{-1}$

$N_{(T)}=$ the number of head of livestock species/category $T$ in the country

$T=$ species/category of livestock

Step 3: Calculating direct $\mathrm{N}_{2} \mathrm{O}$ emissions from manure management

$$
\begin{aligned}
& N_{2} O_{(\text {manure })}=G W P_{N_{2} O} \times\left[\sum _ { S } \left[\sum _ { T } \left(N_{(T)}\right.\right.\right. \\
& \left.\left.\times N_{e x(T)} \times M S_{(T, S)}\right] \times E F_{3(S)}\right] \times \frac{44}{28} \times 10^{-3}
\end{aligned}
$$

Where:

$\mathrm{N}_{2} \mathrm{O}=$ direct $\mathrm{N}_{2} \mathrm{O}$ emissions from manure management in the country, $\mathrm{tCO}_{2}$ e.year ${ }^{-1}$

$G W P_{N 2 O}=265$ : the possibility of causing greenhouse effect of $\mathrm{N}_{2} \mathrm{O}$ compared to $\mathrm{CO}_{2}$

$N_{(T)}=$ number of head of livestock species/category $T$ in the country

$N_{e x(T)}=$ annual average $\mathrm{N}$ excretion per head of species/ category $T$ in the country, kg. $\mathrm{N}^{-1}$.animal ${ }^{-1}$.year ${ }^{-1}$

$M S_{(T, S)}=$ fraction of total annual nitrogen excretion for each livestock species/category $T$ that is managed in manure management system $S$ in the country, dimensionless

$E F_{3(S)}=$ emission factor for direct $\mathrm{N}_{2} \mathrm{O}$ emissions from manure management system $\mathrm{S}$ in the country, $\mathrm{kg} . \mathrm{N}_{2} \mathrm{O}-\mathrm{N} . \mathrm{kg} . \mathrm{N}^{-1}$ in manure management system $S$

$S=$ manure management system

$T=$ species/category of livestock

$44 / 28=$ conversion of $\left(\mathrm{N}_{2} \mathrm{O}-\mathrm{N}\right){ }_{(\mathrm{mm})}$ emissions to $\mathrm{N}_{2} \mathrm{O}_{(\mathrm{mm})}$ emissions

Table 1: Thermal parameters and emission factors of some fuels following IPCC (2006).

\begin{tabular}{|llll|}
\hline Type of fuel & Heat $\left[\mathrm{MJ} . \mathrm{kg}^{-1}\right]$ & \multicolumn{2}{c|}{ Emission factor $\left[\mathrm{tCO}_{2} \mathrm{e} . \mathrm{TJ}^{-1}\right]$} \\
\cline { 3 - 4 } & & $\mathrm{CO}_{2}$ & $\mathrm{CH}_{4}$ \\
\hline Firewood & 30.5 & 112 & 0.03 \\
LPG & 47.3 & 63.1 & 0.001 \\
\hline
\end{tabular}

Table 2: The average amount of biogas production corresponds to the retention time periods.

\begin{tabular}{|llllll|}
\hline Retention time [days] & $6-10$ & $11-20$ & $21-35$ & $36-50$ & $>50$ \\
\hline Biogas production $\left[\mathrm{m}^{3} \cdot\right.$ day $\left.^{-1}\right]$ & 10.87 & 9.18 & 5.30 & 4.14 & 3.38 \\
\hline
\end{tabular}


Step 4: Calculate the amount of $\mathrm{CO}_{2}$ and $\mathrm{CH}_{4}$ emissions from household fuels

$$
\begin{aligned}
& C O_{2(\text { fuels })}=\sum\left(B G_{j} \times N C V_{j} \times E F_{C O_{2 j}}\right) \times 10^{-6} \\
& C H_{4(\text { fuels })}=\sum\left(B G_{j} \times N C V_{j} \times E F_{C H_{4 j}}\right) \times 10^{-6}
\end{aligned}
$$

Where:

$\mathrm{CO}_{2 \text { (fuels) }}, \mathrm{CH}_{4(\text { fuels })}=\mathrm{CO}_{2}$ and $\mathrm{CH}_{4}$ are emissions from fuel burning, $\mathrm{tCO}_{2}$ e.year ${ }^{-1}$

$B G_{j}=$ amount of fuel $j$ consumed annually by the household before the biogas digester is available, $\mathrm{kg}$.year ${ }^{-1}$

$N C V_{j}=$ Heat of fuel $j, \mathrm{MJ}_{\mathrm{kg}} \mathrm{kg}^{-1}$

$E F_{C O 2 j}=\mathrm{CO}_{2}$ emission factor of fuel $j, \mathrm{tCO}_{2} \mathrm{e} \cdot \mathrm{TJ}^{-1}$

$E F_{C H 4 j}=\mathrm{CH}_{4}$ emission factor of fuel $j, \mathrm{tCO}_{2} \mathrm{e} \cdot \mathrm{TJ}^{-1}$

Based on the IPCC guidelines (IPCC 2006), the value of parameters of firewood and gas are shown in Table 1.

Step 5: Calculating total GHG emissions before using the biogas digester

Emissions $_{\text {BEFORE }}=\mathrm{CH}_{4 \text { (manure) }}+\mathrm{N}_{2} \mathrm{O}_{\text {(manure) }}+\mathrm{CO}_{2 \text { (fuels })}+$ $\mathrm{CH}_{4 \text { (fuels) }}$ (6)

\section{Calculating the Amount of GHG Emissions after using the Biogas Digester (IPCC 2006)}

Step 1: Calculating the amount of $\mathrm{CH}_{4}$ released due to leakage from the biogas digester

$$
\begin{gathered}
C H_{4(\text { biogasleakage })}=L F_{C H_{4}} \times\left(G W P_{C H_{4}} \times B_{O}\right. \\
\left.\times D_{C_{4}} \times V S \times 365 \times L N_{2}\right) \times 10^{-3}
\end{gathered}
$$

Where:

$\mathrm{CH}_{4 \text { (biogasleakage) }}=$ the amount of $\mathrm{CH}_{4}$ emissions due to leakage from the biogas digester, $\mathrm{tCO}_{2}$ e.year ${ }^{-1}$

$L F_{C H 4}=$ leakage coefficient $\mathrm{CH}_{4}$ from anaerobic digester, $\mathrm{LF}_{\mathrm{CH} 4}=0.1$

$D_{C H 4}=$ specific gravity of $\mathrm{CH}_{4}, \mathrm{D}_{\mathrm{CH} 4}=0.67 \mathrm{~kg} \cdot \mathrm{m}^{-3}$ under normal conditions

$V S=$ volatile solid waste in pig waste, $\mathrm{kg}$. dry matter $^{-1}$.head ${ }^{-}$ ${ }^{1}$.day ${ }^{-1}$

$L N_{2}=$ average number of pigs in a household with biogas digester, heads/year

Step 2: Calculate the amount of $\mathrm{CO}_{2}$ and $\mathrm{CH}_{4}$ emissions from household fuels

$\mathrm{CO}_{2}$ and $\mathrm{CH}_{4}$ emissions from fuels are calculated similarly to the case when there was no biogas digester.
For biogas fuel, the amount of GHG emissions is calculated by the formula:

$$
\begin{aligned}
C O_{2 \text { (biogas })} & =H \times B_{0} \times D_{C_{2}} \times V S \times 365 \\
& \times L N_{2} \times 10^{-3}
\end{aligned}
$$

Where:

$\mathrm{CO}_{2 \text { (biogas) }}=$ amount of $\mathrm{CO}_{2}$ due to biogas burning, $\mathrm{tCO}_{2} \mathrm{e}$. year $^{-1}$

$B_{o}=$ the maximum $\mathrm{CH}_{4}$ volume generated from pig manure treated in biogas, $\mathrm{m}^{3} \cdot \mathrm{kg}^{-1}$

$D_{\mathrm{CO} 2}=$ specific gravity of $\mathrm{CO}_{2}, \mathrm{D}_{\mathrm{CO} 2}=1.798 \mathrm{~kg} \cdot \mathrm{m}^{-3}$ under normal conditions

$H=$ gas producing efficiency $\mathrm{CH}_{4}, \mathrm{H}=0.9$

Step 3: Calculating the total amount of greenhouse gas emitted after using the biogas digester

Emissions $_{\text {AFTER }}=\mathrm{CH}_{4(\text { biogasleakage })}+\mathrm{CO}_{2 \text { (biogas) }}+\mathrm{CO}_{2 \text { (fuels) }}$ $+\mathrm{CH}_{4(\text { fuels })}(9)$

\section{RESULTS AND DISCUSSION}

\section{Biogas Production}

After constructing the biogas digesters, the households changed to using biogas to cook or produce products as an alternative fuel instead of liquefied petroleum gas (LPG) or firewood. The amount of biogas production was calculated by the formula referenced from IRENA explained in section Method of Calculating the Amount of Biogas Produced. The relevant factors were calculated including average feedstock volume which is $0.39 \mathrm{~m}^{3}$, average retention time is 37.95 days, initial concentration of volatile solids is $66.67 \mathrm{~kg} . \mathrm{m}^{-3}$, and the average yield factor is 6.98 . The results showed that the average amount of biogas production was $5.52 \mathrm{~m}^{3}$ per household per day. A higher rate of gas production was recorded at the shorter retention periods (Table 2) than at longer retention periods.

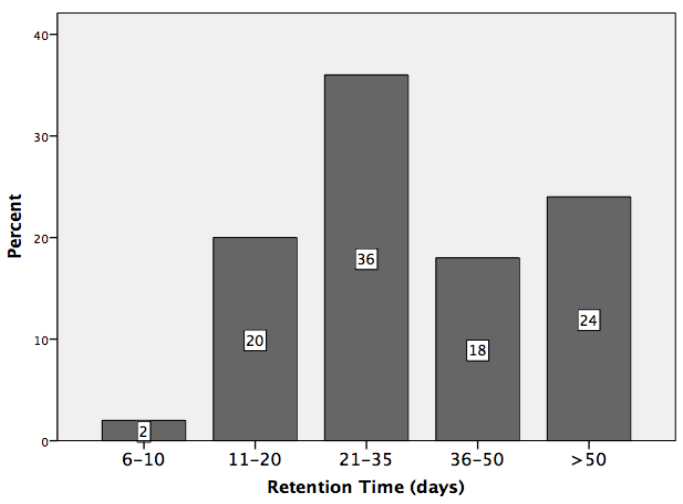

Fig. 3: The retention time on biogas production. 
According to Table 7 in IRENA (2016), when the temperature is between 25 and $27^{\circ} \mathrm{C}$, the yield factor reaches a maximum value of 13.59 when retention time is 6-10 days. When the yield factor has the maximum value, the amount of biogas produced from the digester reaches optimum efficiency. Fig. 3 showed that the number of households using biogas digesters with retention time being 6-10 days only accounts for $2 \%$ of the 50 surveyed households with biogas digesters. With 80 heads of pigs, this household chose to build a biogas digester with a volume of $12 \mathrm{~m}^{3}$ and collected $10.87 \mathrm{~m}^{3}$ of biogas production for serving family activities each day. It is evident that the amount of biogas production they obtained was approximate to the biogas digester volume. The remaining households had a longer retention time, with one family having up to 133 days. Obviously, the surveyed households have not really used the most optimal amount of biogas production.

Decreasing the retention time will reduce the size-and thereby the costs of construction-of the biogas digesters. This study suggests an economic design of biogas digesters by reducing the size suitable for the number of livestock raised. The second solution we recommend is that farmers mix the collected pig manure with other feedstocks consisting of volatile solids such as cereals/grains, rice straw, wheat straw, grass, corn stalks, fruit waste, vegetable waste, fat, mixed food waste, or mixed organic waste.

\section{Reduction of Greenhouse Gas Emissions}

According to our surveyed data from the 50 households with the biogas digesters, $14 \%$ used firewood for cooking, 24\% used LPG, and the remaining $62 \%$ used both before installing a biogas digester. After constructing the biogas digesters, residents could use biogas instead of other fuels such as firewood or gas. There are 41 homes that have stopped using firewood for cooking, accounting for $58.6 \%$ of all households interviewed, and 33 houses that have stopped using LPG, accounting for 47.1 percent of all households interviewed.

The GHG emission from manure composting was calculated following formulas (2) and (3) shown in Section Method of Calculating Greenhouse Gas Emissions Reduction with the parameters corresponding to climatic conditions of Quang Tri Province. Additionally, the number of pigs was obtained from question Q3 in the questionnaire that asks the respondents to provide information about the type and number of pigs they were raising. Based on the information on the number of pigs provided by the households, we calculated the amount of $\mathrm{CH}_{4}$ and $\mathrm{N}_{2} \mathrm{O}$ emissions from the manure management. From these parameters, we obtained the results that the total GHG emissions from manure composting is $12.51 \mathrm{tCO}_{2}$ e.year ${ }^{-1}$. household ${ }^{-1}$ before using the biogas digesters, including $11.52 \mathrm{tCO}_{2} \mathrm{e}$ of $\mathrm{CH}_{4}$ and $0.99 \mathrm{tCO}_{2} \mathrm{e}$ of $\mathrm{N}_{2} \mathrm{O}$. Totally, GHG emissions from 50 surveyed households is $625.37 \mathrm{tCO}_{2} \mathrm{e}$. year ${ }^{-1}$. In particular, $\mathrm{CH}_{4}$ accounts for $92.08 \%$ of total $\mathrm{GHG}$ from composting.

To calculate the amount of greenhouse gases emitted by household fuels including $\mathrm{CO}_{2}$ and $\mathrm{CH}_{4}$, we gathered information on the annual amount of gas and firewood used by each household through questionnaires. Question Q12 was provided to the respondents for the purpose of calculating the amount of fuels used by the households and the cost they paid before constructing the biogas digesters. In the study area, citizens use $12 \mathrm{~kg}$ gas bottles sold by petrol retailers. To obtain information on how much LPG each household used, the question was adjusted to: "How long does it take for your farm to use one $12 \mathrm{~kg}$ bottle of LPG?" The annual amount of gas and firewood used by each household was calculated based on the collected data, from which we computed the

Table 3: Total GHG emissions per year before using the biogas digesters.

\begin{tabular}{|c|c|c|c|c|c|c|c|}
\hline & \multicolumn{2}{|c|}{ From manure pits } & \multicolumn{2}{|c|}{ From using LPG } & \multicolumn{2}{|c|}{ From using firewood } & \multirow[t]{2}{*}{ Total } \\
\hline & $\begin{array}{l}\mathrm{CH}_{4} \text { emission } \\
{\left[\mathrm{tCO}_{2} \text { e.year }{ }^{-1}\right]}\end{array}$ & $\begin{array}{l}\mathrm{N}_{2} \mathrm{O} \text { emission } \\
{\left[\mathrm{tCO}_{2} \mathrm{e} \cdot \text { year }^{-1}\right]}\end{array}$ & $\begin{array}{l}\mathrm{CO}_{2} \text { emission } \\
{\left[\mathrm{tCO}_{2} \mathrm{e} \cdot \text { year }^{-1}\right]}\end{array}$ & $\begin{array}{l}\mathrm{CH}_{4} \text { emission } \\
{\left[\mathrm{tCO}_{2} \text { e. } \text { year }^{-1}\right]}\end{array}$ & $\begin{array}{l}\mathrm{CO}_{2} \text { emission } \\
{\left[\mathrm{tCO}_{2} \mathrm{e} \cdot \text { year }^{-1}\right]}\end{array}$ & $\begin{array}{l}\mathrm{CH}_{4} \text { emission } \\
{\left[\mathrm{tCO}_{2} \mathrm{e} \cdot \text { year }^{-1}\right]}\end{array}$ & \\
\hline $\begin{array}{l}\text { Household } \\
\text { average }\end{array}$ & 11.52 & 0.99 & 0.19 & 0.00000304 & 7.83 & 0.002098 & 20.53 \\
\hline 50 households & 575.83 & 49.54 & 9.60 & 0.000152 & 391.63 & 0.1049 & 1026.70 \\
\hline
\end{tabular}

Table 4: Total GHG emissions per year after using the biogas digesters.

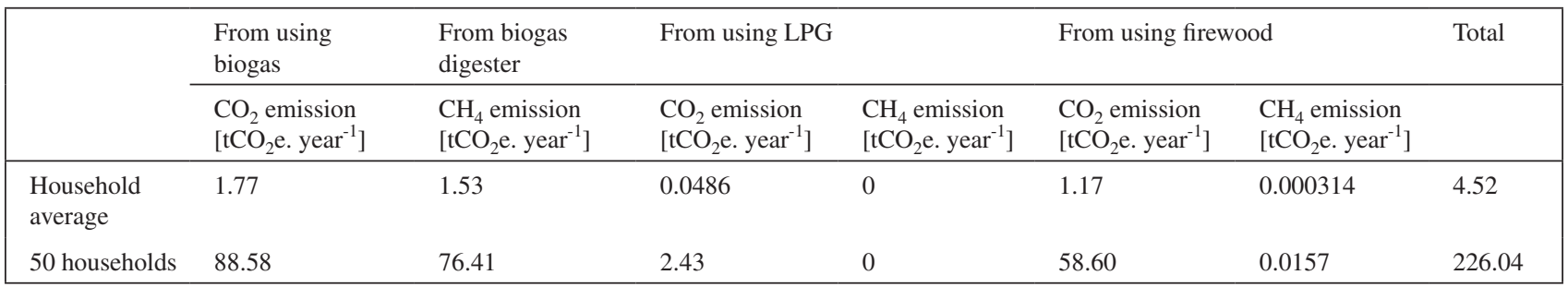


amount of GHG emissions from the fuels using formulas (4) and (5) in Section Method of Calculating Greenhouse Gas Emissions Reduction. On average, each household use 52.58 $\mathrm{kg}$ of LPG per year for cooking needs. The GHG emissions amount from firewood and LPG of 50 households are 401,34 $\mathrm{tCO}_{2}$ e.year ${ }^{-1}\left(8,03 \mathrm{tCO}_{2}\right.$ e.household ${ }^{-1}$.year $\left.{ }^{-1}\right)$, in which the main contributor is $\mathrm{CO}_{2}\left(401,23 \mathrm{tCO}_{2} \mathrm{e}\right.$.household ${ }^{-1}$. $\left.\mathrm{year}^{-1}\right)$, accounting for $99,97 \%$. The total amount of $\mathrm{GHG}$ emissions before using the biogas digesters is equal to the total GHG emissions from manure pits and household fuels. Table 3 showed that with 50 surveyed households before using the biogas digesters, the total amount of GHG emissions into the environment is $1026.70 \mathrm{tCO}_{2} \mathrm{e}$ per year. This is a fairly large number and seriously affects the environment. If the number of households expanded further, GHG emissions amount would increase more. It can be seen that the amount of greenhouse gas emissions from composting and burning fuels is huge. Therefore, without green development solutions, the livestock sector will be a major contributor to climate changes causes.

The emissions from the biogas digesters were calculated based on the number of pigs per household raised in combination with the parameters provided by the IPCC guidelines. Equations (7) and (8) are applied to estimate the amount of $\mathrm{CH}_{4}$ and $\mathrm{CO}_{2}$. The previous fuels have been almost replaced by biogas for cooking or making products. However, biogas generated from the biogas digesters was not enough to completely replace cooking fuels in some households, so they combined biogas for cooking with firewood and gas. The amount of $\mathrm{CO}_{2}$ and $\mathrm{CH}_{4}$ from firewood and gas was calculated similarly as before using the biogas digesters. Table 4 showed that the emission due to leakage from the biogas digesters of the surveyed households is $164.99 \mathrm{tCO}_{2} \mathrm{e}$ per year (3.30 $\mathrm{tCO}_{2}$ e.household ${ }^{-1}$.year ${ }^{-1}$ ) consisting of $88.58 \mathrm{tCO}_{2} \mathrm{e}$ of $\mathrm{CO}_{2}$ and $76.41 \mathrm{tCO}_{2} \mathrm{e}$ of $\mathrm{CH}_{4}$. The amount of greenhouse gas emitted from firewood and LPG is $61.05 \mathrm{tCO}_{2}$ e.year ${ }^{-1}$, which is composed mainly of $\mathrm{CO}_{2}$. The reduction of using firewood and gas has contributed to making a significant reduction in GHG emissions. The amount of $\mathrm{CO}_{2}$ emitted from LPG decreased to a quarter compared to before and the emissions from firewood also decreased from 391.73 $\mathrm{tCO}_{2}$ e.year ${ }^{-1}$ to $58.62 \mathrm{tCO}_{2}$ e.year ${ }^{-1}$. After using the biogas digesters, the total greenhouse gas emissions had reduced to $226.04 \mathrm{tCO}_{2}$ e.year ${ }^{-1}$, less than one-quarter of the $\mathrm{GHG}$ emissions from the surveyed households before using the biogas digesters.

The difference between the amount of greenhouse gas emissions before and after using the biogas digesters was $16.01 \mathrm{tCO}_{2}$ e for each household every year. Straightforwardly, the replacement of daily cooking energies with biogas helps reduce a large amount of greenhouse gases. This is a potential approach chosen to mitigate climate change. In addition, the improvement of this technology also contributes to depreciating firewood consumption and deforestation.

\section{CONCLUSION AND RECOMMENDATIONS}

This study provides an overview of the importance of biogas production using livestock waste in central Vietnam. The daily average amount of biogas production was $5.52 \mathrm{~m}^{3}$ per household, however, this is not the maximum amount of biogas the households can obtain. Despite the good potential for biogas production in central Vietnam, it has not been much developed in the country. In consequence, the economic policies we propose in this article need to be considered for implementation.

A small-scale biogas digester is a very useful manure management tool for reducing global warming impacts. The traditional use of firewood and gas for cooking in central Vietnam was replaced by biogas. The findings of this study showed that the amount of GHG emissions before using the biogas digesters is less than one-quarter of them when biogas was used as an alternative fuel instead of firewood and gas. The annual difference in the amount of GHG emitted before and after the farmers used biogas is $16.01 \mathrm{tCO}_{2}$ e.household ${ }^{-1}$.

Although using biogas as alternative energy helps to reduce the greenhouse gas effect, it cannot be denied that there is still a small amount of greenhouse gases emitted from the biogas digesters. When they are used inappropriately, the amount of biogas will be released into the environment. More in-depth research is needed to come up with the right policies for biogas use. We also suggested that detailed training for biogas users is needed so that users can maximize the benefits they obtain from the digesters. Experimental studies that check and monitor the use of biogas digesters are also essential.

\section{REFERENCES}

Doan, D.T., Nguyen, V.H. and Nguyen, V.L. 2014. Study of climatic drought status in Quang Tri Province. J. Sci. Earth, 36: 160-168.

Hessen, J.V. 2014. An Assessment of Small-Scale Biodigester Programmes in the Developing World: The SNV and Hivos Approach. Institute for Environmental Studies, University of Amsterdam, The Netherlands.

Ho, T.B., Roberts, T.K. and Lucas, S. 2015. Small-scale household biogas digesters as a viable option for energy recovery and global warming mitigation: Vietnam case study. J. Agric. Sci. Technol., A(5): 387-395.

IPCC. 2006. Chapter 10: Emissions from livestock and manure management. Forestry, p.4.

IRENA. 2016. Measuring Small-Scale Biogas Capacity and Production. International Renewable Energy Agency (IRENA), Abu Dhabi, p. 16.

Kinyua M., Zhang J., Fabricio, C.C. and Andres E.T.M. 2016. Use of physical and biological process models to understand the performance of tubular anaerobic digesters. Biochem. Eng., 107, 35-44 
Mayhew, J. 2015. Biogas Rising: The Biogas Industry in Indochina. ASEAN Briefing. https://www.aseanbriefing.com/news/biogas-rising-biogas-industry-indochina/

Mengistu, M.G., Simane, B., Eshete, G. and Workneh, T.S. 2015. A review on biogas technology and its contributions to sustainable rural livelihood in Ethiopia. Renew. Sustain. Energy Rev., 48: 306-316.

Nguyen, V.C.N. 2011. Small-scale anaerobic digesters in Vietnam: Development and challenges. J. Viet. Env., 1(1): 12-18.

Nguyen, V.C.N., Phan, T.H. and Vo, H.N. 2021. Review on the most popular anaerobic digester models in Mekong Delta. J. Viet. Env., 2(1): 8-19.

Quang Tri Department of Agriculture and Rural Development. 2016. Project of Constructing Biogas Digesters, Treating Livestock Waste, Taking Biofuel, Contributing to Environmental Treatment in Household Breeding. Quang Tri Department of Agriculture and Rural Development, Vietnam. Roopnarain, A. and Adeleke, R. 2017. Current status, hurdles, and future prospects of biogas digestion technology in Africa. Renew. Sustain. Energy Rev., 67: 1162-1179.

Teune, B. 2007. The biogas program in Vietnam: Amazing results in poverty reduction and economic development. Boiling Point, 53: 11-13.

Zhang, L.X., Wang, C.B. and Song, B., Carbon emission reduction potential of a typical household biogas system in rural China. J. Cleaner Prod., 47: 415-421. 